\title{
Investigating the Integration Level of Information and Communication Technology (ICT) in the English Language Teaching
}

\author{
Rija Dwiono, Dewi Rochsantiningsih, Suparno \\ Universitas Sebelas Maret, Surakarta, Indonesia \\ Email: rijadwiono@student.uns.ac.id
}

How to cite this paper: Dwiono, R., Rochsantiningsih, D., \& Suparno, S. (2018). Investigating the Integration Level of Information and Communication Technology (ICT) in the English Language Teaching. International Journal of Language Teaching and Education, 2(3), 259-274. https://doi.org/10.22437/ijolte.v2i3.5752

Accepted: October 18, 2018

Published: November 30, 2018

Copyright (c) International Journal of Language Teaching and Education.

This work is licensed under the Creative Commons Attribution International License (CC BY 4.0).

http://creativecommons.org/licenses/by/4.0

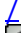
(c) (i)
Abstract

Information and Communication Technology (ICT) is perceived as a part of the core of education in this21st century-learning. Experts have explored the integration of pedagogical ICT in teaching and learning recently. But none of them explored the teacher's competence to integrate pedagogical ICT as they assess the extent to which ICT integrated by the teacher in teaching. This research aims to investigate the teacher competence levels to use ICT and the extent to which the ICT integrated by the teacher in English language teaching. Classroom observation and interview were used as data collecting technique to reach the objectives. To produce an indepth description, this case study focuses on the description of the individual teacher as the target of the investigation. Teacher's ICT competence levels were classified using professional framework rank ICT competence level (UNESCO, 2011). While SAMR model was used as the data analysis tool to determine the extent to which ICT integrated by the teacher in the English language teaching. The results of this research indicate that the teacher's competence to use ICT was still beginner. It means that the teacher is dominant with the use of basic features of presentation, word processor software such as PowerPoint and Microsoft word and other digital resources. It is also reported that teacher's ICT integration level with the domination at the substitution level and augmentation level. These findings reflect the ability of the teacher in integrating ICT in teaching. The teacher is considered only be able to use basic function in a limited number of computer application with only little change and improvement.

\section{Subject Areas}

Language Teaching

\section{Keywords}

English Language Teaching, Information and Communication Technology, Teacher Competence, SAMR model

\section{Introduction}

Advanced technology has been prominent for people and creating technology is not only used for recreation but also as a means of teaching. Teaching in the classroom 
has been transformed with the integration of Information Communication Technology (ICT). The integration of ICT in the classroom is viewed as an important strategy to increase the effectiveness of the teaching-learning process (Mirzajani, et. al., 2016). Researchers already explored the use of ICT in the classroom. They show that integrating ICT assists teacher to develop students' proficiency in teaching (Barreh \& Abas, 2013; Drajati, et. al., 2018; Gheytasi \& Gowhary, 2015; Johnston \& Marsh, 2014; Romrell, et. al., 2014). It can be a medium to facilitate the learning process.

Furthermore, Information and communication technology (ICT) has transformed as a basic building block in the society of this disruptive 4.0 era. Countries around the world perceive that understanding ICT and mastering the basic skill and concepts of ICT is a must. Whereas ICT is also perceived as a part of the core of education, alongside reading, writing, and numeracy. In the education field, to face the industrial revolution 4.0, people are supposed to be able to use ICT in teaching and learning. This also to complete the demand of the $21^{\text {st }}$ century-learning. People are challenged to connect their skill relating communication skills, collaboration, critical thinking, creativity and innovativeness to integrate ICT into their teaching and learning. Those are emerged to get maximum results in teaching.

Hence, educational practitioners must have middle-higher skilled in using technology. Indonesian government pushes the integration of ICT in teaching through the implementation of government regulation concerning teacher Number 74, the year 2008 (Indonesian government, 2008). According to the regulation, the teacher must be able to use ICT as a means in teaching. Moreover, teacher proficiency to integrate ICT in teaching is required for the teacher certification. It can be seen that the ability to integrate ICT in teaching is a mandate for the teachers as a realization of Indonesian government policy to push the integration of ICT in teaching. For that reason, integrating ICT in teaching is a vital aspect which should be aware for teachers in teaching.

Meanwhile, the integration of ICT in teaching remains barriers. Technological innovation is rapidly changing which makes it hard to follow for teachers. The teachers require to learn and adapt how to manage learning behavior differently as they use ICT in the classroom (Kucirkova, et.al., 2014). Most of the teachers are unable to integrate technology in learning because of their lack of proficiency. Teachers get frustrated when they try to integrate new ICTs into the existing curriculum (Potter \& Amanda, 2012). Eventually, it makes the ICTs used in learning become less effective and could be disregarded.

By conducting a preliminary research in a school in Pringsewu district, Lampung province. The researcher found that the teachers have been integrating ICT in the teaching-learning process. The integration of ICT has spanned across school subjects among the schools included in the English Language Teaching. In fact, the teachers stated that the adoption process of the integration ICT in teaching faces problems and barriers. They added that the sources problems are coming from the external and the internal factor, including the insufficient training for them to integrate pedagogical ICT as well as their competence to operate pedagogical ICT in teaching. While the effectiveness of the ICT relies on the teacher's creativity to manage and to create interesting learning activities that the teacher is going to use. Teacher competence is a vital aspect of the integration of ICT in teaching. It will, of course, influence how the teachers integrate ICT in their teaching.

Moreover, pedagogical training on the integration of ICT in teaching has an important role to elevate the teacher competence. The lack of teacher training in computer skills is a major problem which has been well documented in the literature (Anderson et al., 1984). It can be stated that without sufficient training to integrate ICT in teaching for the teacher might affect a miss conception of how ICT is being used by teachers in learning for students in the classroom, eventually, it will influence the quality of teaching. 
Therefore, it is necessary toassess the teacher's ICT competence level and the extent to which the teachers integrate pedagogical ICT in the English Language Teaching.Then the current practices on the integration of ICT can be evaluated and it can be used to plan the integration of ICT in teaching based on documented needs. Hence, the researcher used a tool that can be used to determine and classify the integration of pedagogical ICT in learning, SAMR model (Puentedura, 2006). The SAMR integration model benefits in reflecting and evaluating four distinct level for the integration ICT may be used in learning. (Romrell et al., 2014)SAMR is integrated and systematic framework which each classification represents the level of the ICT integration. By using SAMR model, levels of the teacher in integrating ICT in learning can be reflected and classified.

Several scholars and experts have explored the integration of pedagogical ICT and SAMR model in teaching and learning recently. (Batiibwe, et. al., 2017; Budiman \& Ngadiso, 2018; Cochrane \& Antonczak, 2014; Hilton, 2016; Jude, et. al., 2014; Kihoza, et.al., 2016; Romrell et al., 2014; Speirs, 2016). But none of them explored the teacher's competence to integrate pedagogical ICT in teaching while teacher competence to use ICT influence the extent to which ICT integrated by the teacher. As what research have explored that the knowledge and competencies of teachers to integrate pedagogical ICT are keys attributes for the future of education success (Kihoza, et. al., 2016). Literatures have documented that lack of ICT use innovate skills and also the low level of technological knowledge leads to low usage of classroom ICT integration among teachers (Andersson, et. al., 2014). Without a high competence to use ICT, we should not expect teachers on integrating ICT in their professional practices to be optimum (Brás Pedro, 2014). It can be concluded that ICT use competence level is a fundamental factor influencing ICT usage by teacher in the classroom. It is necessary to investigate the teacher competence level to integrate ICT as we assess the extent does the teacher integrate ICT in the classroom. Hereby, this research attempts to describe (1) the teachers' competence levels to use ICT and (2) the extent to which the ICT integrated by the teacher in English Language Teaching.

\section{Literature Review}

\section{Information and Communication Technology (ICT)}

ICT is an acronym which stands for information and communication technology. Information and Communication Technology is all of devices relate to taking, collecting, accessioning, processing, saving and spreading of the information (Research and technology ministry, 2006). Warsita (2008) Information and Communication Technology is of hardware and software and the method to gain, send and processing the data meaningfully. UNESCO (2003) stated that Information and Communication Technology generally relates to those technologies that are used for accessing, gathering, manipulating and presenting or communicating information. The technologies could include hardware e.g. computers and others devices, software applications, and connectivity e.g. access to the internet, local networking infrastructure, and video conferencing. In addition, according to Tomy in (Lloyd, 2005) ICT

...generally relates to those technologies that are used for accessing, gathering, manipulating and presenting or communicating information. The technologies could include hardware (e.g. computers and other devices); software applications; and connectivity (e.g. access to the Internet, local networking infrastructure, Videoconferencing). What is most significant about ICT is the increasing convergence of computer-based, multimedia and communications technologies and the rapid rate of change that characterizes both the technologies and their use. 
It can be concluded that Information and Communication Technology (ICT) is described as the technology used to manage the information and aid the communication invoking software and hardware to gaining, collecting, accessioning, processing, saving and spreading data and or information.

\section{Integrating ICT in Education}

There are aspects need to be taken into account as the ICT integration in education. The use of ICT in learning does not replace the traditional face-to-face instruction, yet it is used as a supportive tool in learning. Hence, the effectiveness of ICT use in teaching relies on the teacher's creativity to manage and to create interesting learning activities for students. Teachers require to learn and adjust how to manage learning behavior differently as they integrate ICT in teaching (Kucirkova et al., 2014). Teachers must guide students in the learning process and provide them with the suitable learning strategies to ICT integration in learning.

Meanwhile, studies have shown that the lack of teacher training in computer skills is a major problem in the ICT integration in education (Anderson et al., 1984). Teachers do not only play as the information provider and guide the students but also become supporter and facilitator in learning. It can be concluded that to optimize learning activity integrated with ICT it necessary to be supported by middle-higher skilled teachers to use ICT in teaching.

\section{The concept of ICT in Teaching and Learning}

There are some aspects which are necessary to consider the integration of ICT in teaching and learning, such as qualified/skilled personnel to integrate technology, access to pedagogical ICTs is exists, sufficient infrastructure to support pedagogical ICTs integration is exists, training is provided for pedagogical ICTs, operational staff in ICT Unit, sufficient budget to support for pedagogical ICTs is exist (Pelgrum, 2001).

Moreover, Mahmud (2008) stated that there are some requirements in applying ICT in the process of teaching and learning. They are: school is provided by means and infrastructure enabling the integration of ICT. The teacher and the students must fulfill these components in integrating ICT as a means in teaching, they are; teacher and student have accessibility to use technology and connect to the internet in the classroom, school, and institution, teacher provides qualified and meaningful learning material, teacher have knowledge and skill to use the device and other digital resources to aid student due to achieve learning objectives, the institution has an adequate budget to provide, develop, and maintain the ICT, the existence of willingness from the teachers, students, stakeholder, and all components to integrate technology in the school/institution.

\section{ICT Competence Level}

Level integration in teaching relates to the ICT knowledge and competence level of the users. The competences of teacher to use ICT in pedagogical application is highly influenced by knowledge that they receive. (Thomas, et.al., 2013). Literatures have well documented that lack of ICT use innovate skills and also low levels of classroom ICT integration among teacher as the low level of technical knowledge leads to low usage (Andersson, et. al., 2014). Teachers ICT use competencies are well defined by a collection of knowledge, skills, understandings, and attitudes that are inseparably assured with context and pedagogy (Doyle \& Reading, 2012). 
Furthermore, the increase in teachers' ICT knowledge triggers the use of technology in their activities. Without a high ICT Knowledge, we should not expect teachers' competence to use ICT in their professional practices to be optimum (Brás Pedro, 2014). UNESCO (2011) teacher professional framework rank ICT competence level into three categories: (1) beginners (ability to perform basic functions in a limited number of computer applications), (2) average users (ability to use a number of computer applications), (3) and advanced user (ability to competently use a broad range of devices and tools). Those categories are used to assess teachers' ICT competence in English teaching.

\section{SAMR Model}

The SAMR model is a tool for assessing and evaluating technology practices and impacts in a classroom setting by looking into students, teachers and the changes (Myers, 2017; Puentedura, 2013). Teachers can determine their technology levels as they experience shifts in the design of technology-based learning artifacts and application of technology-driven learning to achieve the next level (Ahrens \& Zaščerinska, 2014).

Then this model is considered as the most suitable model with the objective of this research since SAMR is used as a tool to determine and classify the level of ICT pedagogical integration and SAMR was developed based on the teaching process which is the core of this research. Puentedura (2006) classified SAMR has four different levels of the ICT use which can be identified in teaching, namely Substitution, Augmentation, Modification, and Redefinition. It is described in the picture below: 


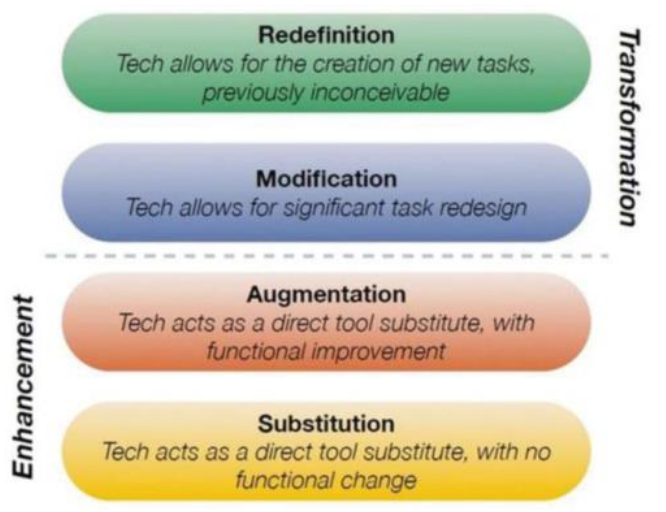

Figure 1. SAMR model. (Puentedura 2013.)

Substitution is the use of technology for a task that could be accomplished without technology. Augmentation provides a technological improvement for a task that could be completed without technology. Modification allows for a pre-existing task to be significantly altered in a way not possible without technology. Finally, redefinition would be the creation of a completely new task not possible without the technology.

\section{Method}

The design of this research is a case study. Dey (2005) stated that a case study approach more commonly associated with qualitative methods. Briefly, a case study is the types of qualitative method. The researcher described the result of the research based on what the researcher collects from the data and its experiences. This case study research focuses on the description of the individual teacher as the target of the investigation. A case study itself is typically used as a researcher plans to focus on a single unit to produce an in-depth description that is rich and holistic (Ary, et. al., 2010).

The participants of research must meet certain criteria in order to be included in a study. By using purposive sampling, participants qualified to participate in this research was an English teacher who involved in teaching and learning process in the English classroom. The teacher was selected as the research subject because she has been integrating ICT within her English teaching. The underlying principle of selecting this research design and the teacher is due to the fact that the purpose of this research is to get a depth understanding on teacher's competence level as well as the extent to which the teacher integrate ICT in the English language teaching. Therefore, the study was targeted only to D (false name) who is considered as an English teacher who is able to provide data due to answer the research questions.

In order to gain validity of the data, the researcher conducted observation and interview as triangulation to get the data of this research. Observation checklist was used to observe the teacher's and the students' behaviors. The researcher also took field notes on the behavior and activities of individuals at the research site. The SAMRbased observations were done three times as the teaching and learning process on the particular in English Language Teaching with the use of ICT was completed in three meetings. Moreover, the researcher used semi-structured interview. The answers were open-ended, and there was more emphasis on the interviewee elaborating points of interest. One hour interview was done once to the respondent after the last classroom observation.

In addition, member checking was used in this research. The interviewee was 
asked for confirmation of the data that have been found in the observation and interview. This technique is used in order to verify the researcher's interpretations and conclusions with the interviewee herself (Denzin \& Lincoln, 2005). Then, it is aimed to reach an agreement on the classification of the extent to which ICT integrated by the teacher in the English Language Teaching.

In the data analysis, the researcher analysed the data right after the researcher got the data from the observation sheet and interview. The researcher analysed the data based on interactive modal (Miles, Huberman, \& Saldana, 2014). The phases of activity were; 1). Data Condensation. The researcher do the process of selecting, focusing, simplifying, abstracting and transforming the data that appear in written up field notes. Then, the data were organized and reduced or reconfigured. In this case, the researcher selected the data derived from observation on teaching and learning process and interviewing to the English teachers. 2). Data Display. In this stage, the result of data condensation is organized into 1 figure and 4 tables. The figure is showing classroom observation result of teacher's competence level to use ICT. And the 4 tables describe the SAMR-based observations result. It is ordered by the level in the SAMR model, namely Substitution, Augmentation, Modification, and Redefinition. 3). Conclusion Drawing/Verification. After the data is considered have constancy, fixed conclusion of the data were drawn in order to be written in the research finding report. In addition, the data found from the whole three classroom observation were analysed quantitatively by using Microsoft Excel and displayed in the form of percentages. Then, the data were described qualitatively in order to give a clear description for the readers.

\section{FINDING AND DISCUSSION}

\section{Teacher's Competence Level to use ICT}

While the teacher has been integrating ICT in their English teaching. The teacher's competence to use ICT was assessed by doing observation. After the observation was done, the researcher conducted the interview to find a better understanding of the raised issue from the target of the investigation. The teacher's competence level assessed were adapted from the ICT teacher competency framework by UNESCO(2011). They were ranked as (1) beginners (ability to use basic function in a limited number of computer applications), (2) average users (ability to use a number of complex computer applications), (3) and advanced user (ability to competently use a broad range of devices and tools). The result of observations when the teacher was teaching English in three meetings is simply described in the following figure:

Figure 2. Showing teacher's competence level to use ICT 


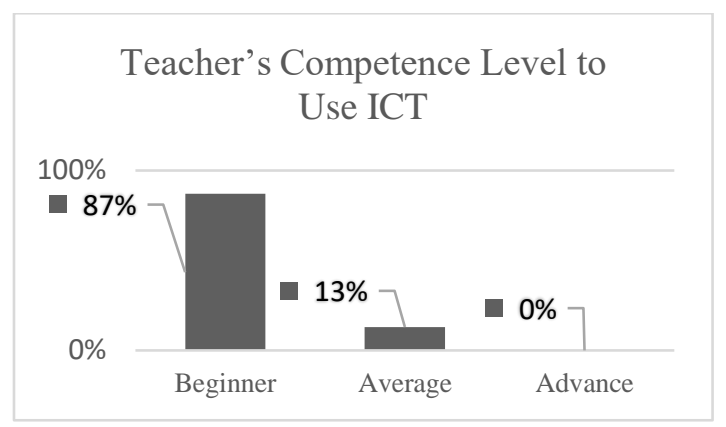

From the result of the classroom observation, it revealed that the teacher was dominant to use ICT at beginner level (87\%). It shows that the teacher is able to use basic operation of various types of hardware, such as desktop computers, laptops, printers, and hand-held devices. The teacher also can use the basic features of presentation, word processors software such as PowerPoint and Microsoft word and other digital resources. At this stage, the teacher is considered only can use basic function in a limited number of computer application. In addition, although some devices such as Hand Phone and laptop were not provided by the school in teaching. The teacher still have them because the teacher has had the ICTs since she was in the college. The teacher does not seem to have any difficulties to use those ICTs. She used those ICTs in teaching for several activities, either during the process of teaching and learning or during the preparation before teaching in the classroom. Likewise, when the teacher was interviewed whether she could use basic operation of various types of hardware such as laptops, hand-held devices, LCD; and software such as word processor, excel, and power point. She describes her competence to use the ICTs in teaching:

I can operate some kind of ICTs. I often use Hand Phone, laptop or PC computer to prepare my teaching materials. I use Microsoft word to type the teaching material since sometimes I need to print out the materials which are not provided within the students' book. I use PowerPoint and LCD projector to present the teaching material in front of the classroom. Moreover, I also use Microsoft Excel to create a draft of students score, and rank the students' achievement. Furthermore, I check my teaching material, such as the grammar, spelling in English using Microsoft word. I can handle those basic ICTs since I often used to those when I was in the college.

In addition, similarly with the teacher's competence to use the basic ICTs and word processor. At the beginner level, it shows that the teachers are able to use graphics software, a browser, search engine and create an email account as a means in teaching. In three meeting observed, the teacher always uses laptop, speaker as well as LCD projector that has been provided in the classroom. The teacher presents the teaching material in front of the classroom using pictures, sounds, slides, and videos. Furthermore, the teacher also has the students in the group to create and present their digital poster about English advertisement in front of their peers using their smartphones or laptop. After presenting their poster, the teachers have the students to upload their digital poster on Facebook. Then they were asked to give comment about their peers' poster and performances. Although the teacher only did this activity only for once, this shows the teacher is able to use several basics ICTs in delivering teaching material in the classroom. She explains her competence to use those basics ICTs when she was asked why the teacher use the ICTs and how the teacher utilizes the ICTs as a means in teaching:

Attracting students' interest and to motivate students in learning is very 
important. Then I use ICTs, such as movie maker to combine pictures, videos and sound then it regenerates to be a new interesting video as a media in teaching. I also use software such as Pics art and Canvass to have students create caption or poster. However, I do it rarely because it spent a lot of my energy and time. WiFi hotspots have been already provided in this school, then I often use the internet especially using a search engine such as google or yahoo to search teaching materials, picture and any information relating to English Language teaching. Then sometimes I let students search and use website platform to find any English learning resources, such as watching video on YouTube, creating a poster in Canvas, Giving peer feedback on social media. Then they can have reallife practice during the process of teaching and learning.

The second level achieved by the teacher is average level with the percentage of $21 \%$. The teacher in this level only could describe and use only a few complex ICTs tool such as online communication invoking online messaging or social media and online database such as google drive to manage their file in their laptop. It means that the teacher is considered has limited competence to perform a number complex ICTs tool, such as use authoring environment to design online material, operate various open-ended software as well as the use of network and appropriate software to manage, monitor and assess students project. She describes her understanding about the provided list of ICTs in the average level and describes ICTs in the average level used in teaching below:

I never know an authoring environment or tools to design online materials or even to use it. I just give students the material in the classroom, in the social media or in WhatsApp if it is necessary. I don't use blog and web since it is very complicated. Moreover, when I use those platform I need to manage and maintain them, it will be time-consuming. I just can describe and understand some basics ICTS, I do not know about the relatively new ICTs such as MOOC, software to manage the progress of various student projects or the network to support student collaboration as what you explained.

At the third level was the advanced level. It comprised $0 \%$ regarding the teacher's competency to use various networked devices, digital resources and electronic environments used to create the production of knowledge and 'anytimeanywhere' collaborative learning. It showed that the teacher never uses any a broad range of devices like using multimedia recording, production equipment, publication software, and web design tools. In this case, the teacher has insufficient information and training that might hinder to use those devices and tools. Meanwhile, studies have well explored that lack of training is a major problem for the teacher to use pedagogical ICT in teaching(Anderson et al., 1984). As interviewed the teacher about ICTs invoked in advanced level as a means in teaching such as, publication software, web design tool and production equipment, she answered:

I don't understand and don't familiar with those kinds of ICTs. The development of the ICT grows too fast for me. There is a lot of new kind of devices and tools that can be used in teaching English perhaps. I do not get any information about it then how I can use those new technologies. In addition, I live in a village that far enough from the city, I live with people who do not aware about the use of ICT even in their daily life. Moreover, I never attend any training to use pedagogical ICT. The school doesn't provide it yet. Then, I do not get adequate information and knowledge about it and how to use it. Those situations make me hard to follow the development of pedagogical ICT and to use to use it in teaching. Then the pedagogical ICTs that I used in the classroom are limited. 


\section{The extent to which the ICT integrated into the English Language Teaching}

The aim of this section is to explore the extent to which the ICT integrated into English Language Teaching. The researcher used SAMR as a tool to assess the teacher ICT integration level since the SAMR is considered as the most suitable model to classify the level of ICT pedagogical integration. SAMR model provides a framework to describe and classify different levels of ICT integration (Puentedura, 2006). Furthermore, the instrument for the observation sheet used to assess the integration level of ICT using SAMR model is adapted from Jude et al., (2014). It is separated within four level of the ICTs integration level namely Substitution ICTs, Augmentation ICTs, Modification ICTs, and Redefinition ICTs. From the result of the observation that has been done in three meetings. Then, it is confirmed by doing member checking with the teacher D (false name) as the research subject regarding the extent to which ICT integrated into English Language Teaching. It is described as follows:

Table 1. Observation table of Substitution ICTs Used by the Teacher in the English Language Teaching

\begin{tabular}{|c|c|c|}
\hline No & Class activity & Mean \\
\hline 1. & $\begin{array}{l}\text { Use ICTs (e.g. laptop, hand phone, Microsoft word) to prepare } \\
\text { her lecture, assignments, and examinations }\end{array}$ & $100 \%$ \\
\hline & Use digital taking note instead of a printed notebook. & $66,7 \%$ \\
\hline & Use the PowerPoint presentation method to deliver lectures & $100 \%$ \\
\hline & $\begin{array}{l}\text { Upload the teaching and learning materials on Facebook or } \\
\text { other electronic sites/devices for students to access. }\end{array}$ & $66,7 \%$ \\
\hline & $\begin{array}{l}\text { Refer students to electronic databases for reference materials } \\
\text { instead of hard copy textbooks }\end{array}$ & $100 \%$ \\
\hline & $\begin{array}{l}\text { When supporting her students, the teacher communicates to } \\
\text { them using her cell phone. }\end{array}$ & $100 \%$ \\
\hline & $\begin{array}{l}\text { When supporting the students, the teacher communicates to } \\
\text { them using e-mail. }\end{array}$ & $33,3 \%$ \\
\hline & $\begin{array}{l}\text { When supporting the students, the teacher communicates to } \\
\text { them through social media such as Facebook, Twitter, chat } \\
\text { rooms, and discussion boards. }\end{array}$ & $66,7 \%$ \\
\hline & $\begin{array}{l}\text { Prefer students to submit their coursework assignment } \\
\text { through email }\end{array}$ & $33,3 \%$ \\
\hline & $\begin{array}{l}\text { Have specific folders in her laptop to manage file of her } \\
\text { students' works. }\end{array}$ & $100 \%$ \\
\hline & $\begin{array}{l}\text { Record her lectures on CDs/other media and give them to her } \\
\text { students }\end{array}$ & $0 \%$ \\
\hline & $\begin{array}{l}\text { Take video/audio recordings of herself while lecturing and } \\
\text { uses them in subsequent years to teach the same course to } \\
\text { another cohort of students }\end{array}$ & $0 \%$ \\
\hline & Grand Mean & $40,9 \%$ \\
\hline
\end{tabular}

Table 2. Observation Table of Augmentation ICTs Used by the Teacher in the English Language Teaching

\begin{tabular}{llc}
\hline No & \multicolumn{1}{c}{ Activity } & Mean \\
\hline 1. & $\begin{array}{l}\text { Highlighted text in the digital device with color and different } \\
\text { font size. }\end{array}$ & $100 \%$ \\
\hline 2. & $\begin{array}{l}\text { Use search engines (e.g. Google) to look for the reference to the } \\
\text { teaching material }\end{array}$ & $100 \%$ \\
\hline
\end{tabular}


3. Use the editorial tools in the word processor to correct $100 \%$ grammatical errors in any documents

4. Use the editorial tools in the word processor to receive $33,6 \%$ alternative words to use in essays

5. Use digital libraries (e.g. Digilib, MuLib) as a source of useful $\quad 0 \%$ content for the lectures

6. Use Internet group lists to contact students in matters related $33,6 \%$ to their academics

7. Modify the folder to be more attractive and order the folder by $100 \%$ its name then it can be found it easily.

8. Use bulk messaging to contact students in matters related to $66,7 \%$ their academics

9. Subject students' work/teaching material to a plagiarism test $\quad 0 \%$ using plagiarism detection software

10. Provide feedback to students' reports, papers and assignments $\quad 33,6 \%$ through their social media or email

Grand Mean

Table 3. Observation Table of Modification ICTs Used by the Teacher in the English Language Teaching

\begin{tabular}{rlc}
\hline No & \multicolumn{1}{c}{ Activity } & Mean \\
\hline 1. & $\begin{array}{l}\text { Ever combined audio, video, and text notes in presenting } \\
\text { material using an application such as "movie maker" }\end{array}$ & $66,7 \%$ \\
\hline 2. & $\begin{array}{l}\text { Include a hyperlink to online dictionaries and other sources to } \\
\text { the teaching material }\end{array}$ & $0 \%$ \\
\hline 3. & $\begin{array}{l}\text { Administer multiple choice questions for tests/examinations } \\
\text { through google form or other devices }\end{array}$ & $33,3 \%$ \\
\hline 4. & Use Google Drive to manage and collect files of students' works. & $33,3 \%$ \\
\hline 5. & $\begin{array}{l}\text { Lecture modules in the discipline using e-learning platforms } \\
\text { (e.g. MUELE, Edmodo) }\end{array}$ & $33,3 \%$ \\
\hline
\end{tabular}

6. Use open education resource to use group discussion facility $66,7 \%$ (e.g. Blog, Social Media, Web).

7. Use online tools (e.g. RM Assessor) to assess students $0 \%$ achievement/score

8. Use note taking application such as "Sling Note, Google note" $0 \%$ program to curate online sources.

9. Use video conferencing or Skype to teach students when the $0 \%$ teacher not at the school Grand Mean

Table 4. Observation Table of Redefinition ICTs Used by the Teacher in the English Language Teaching

\begin{tabular}{rlc}
\hline No & \multicolumn{1}{c}{ Activity } & \multicolumn{1}{c}{ Mean } \\
\hline 1. & $\begin{array}{l}\text { Include audio, video, and other interactive online platforms to } \\
\text { use as the multimodal teaching material. }\end{array}$ & $33,3 \%$ \\
\hline 2. & $\begin{array}{l}\text { Share digital notebook or using a certain application to develop } \\
\text { note-taking. }\end{array}$ & $0 \%$ \\
\hline 3. & $\begin{array}{l}\text { Create a multimodal task to make the instruction more real, } \\
\text { interesting and challenging for students. }\end{array}$ & $0 \%$ \\
\hline 4. & $\begin{array}{l}\text { Use open education resource as my study materials (e.g. } \\
\text { MOOC) }\end{array}$ & $0 \%$ \\
\hline 5. & $\begin{array}{l}\text { Use e-learning platforms (e.g. Near Pod, MOOC) to assess my } \\
\text { students' learning }\end{array}$ & $0 \%$ \\
\hline
\end{tabular}




\begin{tabular}{llc} 
6. & Use augmented reality when teaching. & $0 \%$ \\
7. Use electronic games when teaching. & $33,3 \%$ \\
\hline Grand Mean & $\mathbf{6 , 2 \%}$
\end{tabular}

The results of the observation table above show that the ICT integrated by teachers in English language teaching with the domination at the substitution level and augmentation level at the second place. It means that the teacher was under the area of "Enhancement". The substitution ICTs used comprised 40,9\%. At the second level achieved was augmentation with percentage $36,3 \%$ and followed by modification $(16,6 \%)$ and redefinition $(6,2 \%)$. It means that the teacher was dominant on integrating ICT to substitute the use of electronic databases instead of hard copy textbooks and make little change or improvement from the original one. She prefers to make use of electronic databases since she has already got the soft file instead to use of hard copy textbook. With the domination at the substitution level in teaching English in the classroom, the teacher has been observed almost every teaching does the same thing. She Uses ICTs (e.g. laptop, hand phone, Microsoft word) to prepare her lecture, assignments and examinations and PowerPoint presentation method to deliver lectures with the purpose to be more interesting and more effective to prepare as well as to deliver the material in teaching. Moreover, she also uses hand handled device outside the school to support the teaching and learning in the classroom. The intention is just to change using nontraditional teaching strategies from hard copy textbook into a soft file display without any improvement or change (Puentedura, 2013). The implementation of this substitution level is done by the teacher, it is as described below:

I always make use laptop, hand handled devices such as hand phone or tablet to teach students inside or outside the classroom. I use it as a means to help me in creating more interesting and effective teaching. I also use word processor such as Microsoft word office to type my teaching material and PowerPoint to present the material. While the time is limited if I only teach students in the classroom so I must support it by giving them additional class using ICTs, such as social media like Facebook, email, or text massaging. I prefer students to be electronic databases, then sometimes I use social media or email to give soft copy material and to submit their task instead of printed text. I also always use digital text since the soft file of the textbook has been provided by the government as well. I use those ICTs only to give students better experience in learning using ICT than using traditional teaching strategies.

Furthermore, the teacher also uses electronic equipment to make several changes on her teaching strategies, such as highlighted text in the digital device with color and different font size, uses an electronic dictionary and make use the editorial tools in word processor either to correct grammatical errors or to receive alternative words to use in any documents. The ICT integrated by the teacher in this activity reaches augmentation level. The teaching material is different from the original one since she has already made several changes on the teaching material for the sake to enhance learning. The augmentation level reached by teacher comprised $36,3 \%$ which means the teacher actually has already often made any change or improvement on her teaching material. In the augmentation level she did integrate ICT in teaching, she explained:

I also make several changes to my teaching strategies in using ICT. Highlighted text in digital my presentation material such as in PPT and Microsoft word with color and different font size, add pictures or moving animation then my students will be easier to focus and easier to understand and also it is intended to attract their interest in learning. I also use the editorial tools in word processor either 
to correct the grammatical in my documents or use the editing tools in the word processor to receive alternative words in designing my teaching material or lesson plan.

In addition, concerning managing the teaching material, the teacher also made changes or improvement using ICT. The teachers make use online text messaging. She stated that she used bulk messaging to contact students in matters related to their academics. And the teacher saves any document related to the teaching and learning in the computer in the form various folder. She orders the folder by its name and makes changes the color of every folder so each folder will be easier to recognize and attractive to see. It is as described below:

I also use the broadcast message or bulk messaging to contact students regarding their academic. Moreover, it helps me to send messages only for once, then I don't need to send the messages each student one by one. About managing my document relating to teaching and learning, I order it by name then I can find it easily and I also design it colorfully that make it looks more attractive.

Further, the teacher was observed inserted hyperlink to online resources in her teaching material for students to access. The teacher also ever combines video, picture, audio and text note in presenting material in teaching. To help him conduct quiz for students she administers multiple choice questions for tests/examinations through google form so the teacher will easily check and collect the students' answers. Moreover, the teacher lectures modules in the discipline using e-learning platforms and also uses open education resource to use group discussion facility. In this case, the teacher has reached modification level with the percentage of $16,6 \%$. However, the teacher rarely does the activities as observed in the teaching and learning process. It is in lined with the teacher's statement that she rarely does those activities because they are time-consuming and spent a lot of energy. She described:

I movie maker to combine pictures, videos and sound then it regenerates to be a new interesting video as a media in teaching. Using ICT to conduct the test sometimes I administer multiple choice questions for tests/examinations through google form or other devices in order to help me to collect students' answers and avoid heaps of paper to mark. However, I do it rarely because it spent a lot of my energy and time.

The least ICTs used by the Teacher in the English language teaching is Redefinition level in SAMR model. It can be seen from the observation result that the teacher only used two kinds of teaching strategies using ICTs in teaching. Moreover, the percentage of ICTs used by the teacher at redefinition level was too low. The teacher only achieved 6,2\% at redefinition level in SAMR model. It indicates that the teacher could hardly use ICTs at the redefinition level. At this level the teacher combined videos, PPT, text, sound, and picture to create multimodal text. The other ICTs used was an electronic game inhttps://play.kahoot.it.However, the teacher only used the ICTs once from the whole three times classroom observation. The teacher explained:

I combine PPT, with pictures, sounds, and videos to create another new video, then I could create new strategies in learning. I also use software such as Pics art and Canvass to have students create caption or poster. Using complicated ICTs is very time-consuming. Even when I have limited knowledge about how ICTs used for. Moreover, sometimes I have limited access to the internet. As the internet was too slow I avoid using the internet to teach students, hence I cancel to use the electronic game in the web like in Kahoot.it. 


\section{Conclusion}

It is found that the teacher's competence to use ICT was still beginner. It means that the teacher is dominant with the use of basic features of presentation, word processor software such as PowerPoint and Microsoft word and other digital resources. The teacher's competence level to use ICT is in lined with teacher's ICT integration level with the domination at the substitution level and augmentation level as it is analyzed using SAMR model. These ICT levels of the integration reflect the ability of the teacher to integrate ICT in teaching that the teacher is considered only be able to use basic function in a limited number of computer application with only little change and improvement. However, the teacher more often integrates the ICT to only substitute the use of printed textbook with the digital material without any changing or improvement.

This finding supports the previous research that the competences of teacher to use ICT in pedagogical application is highly influenced by knowledge that they receive. (Thomas et al., 2013). Without a high competence to use ICT, we should not expect teachers on integrating ICT in their professional practices to be optimum (Brás Pedro, 2014). In addition, some problems occurred during the integration of ICT in teaching and learning process. Especially the lack of access to the internet at school and insufficient pedagogical ICTs training for the teacher. While accessibility to connect to the internet is required as the teacher integrates ICT in teaching (Mahmud, 2008). Moreover, studies have shown that the lack of teacher training in computer skills is a major problem in the ICT integration in education (Anderson et al., 1984). These problems might be the reasons which hinder the teacher to reach higher ICT integration level in SAMR model.

\section{References}

[1] UNESCO. (2011). Unesco Ict Competency Framework for Teachers. (P. Hine, Ed.) (2nd ed.). Paris: The United Nations Educational.

[2] Mirzajani, H., Mahmud, R., Fauzi Mohd Ayub, A., \& Wong, S. L. (2016). Teachers' acceptance of ICT and its integration in the classroom. Quality Assurance in Education, 24(1), 26-40. https://doi.org/10.1108/QAE-06-2014-0025

[3] Barreh, K. A., \& Abas, Z. W. (2013). A Framework for Mobile Learning for Enhancing Learning in Higher Education. Malaysian Online Journal of Educational Technology, 3(3). Retrieved from www.mojet.net

[4] Drajati, Nur Arifah, and Tan, and Tan, Lynde Haryati, and Haryati, Sri, A., \& Zainnuri, and Rochsantiningsih, Dewi, and Zainnuri, H. (2018). Investigating English Language Teachers in Developing TPACK and Multimodal Literacy. Indonesian Journal of Applied Linguistics, 7(January), 575-582. https://doi.org/10.17509/ijal.v7i3.9806

[5] Gheytasi, M., \& Gowhary, H. (2015). The effect of smartphone on the reading comprehension proficiency of Iranian EFL learners. Procedia - Social and Behavioral Sciences, 199, 225-230. https://doi.org/10.1016/j.sbspro.2015.07.510

[6] Johnston, N., \& Marsh, S. (2014). Using iBooks and iPad apps to embed information literacy into an EFL foundations course. New Library World, 115(1/2), 51-60. https://doi.org/10.1108/NLW-09-2013-0071

[7] Romrell, D., Kidder, L. C., \& Wood, E. (2014). The SAMR model as a framework for evaluating mLearning. Journal of Asynchronous Learning Network, 18(2), 115.

[8] Indonesian government. Peraturan Pemerintah Republik Indonesia Nomor 74 Tahun 2008 Tentang Guru (2008). Retrieved from http://unnes.ac.id/wp- 
content/uploads/PP_74_Tahun_2008.pdf

[9] Kucirkova, N., Messer, D., Critten, V., \& Harwood, J. (2014). Story-making on the iPad when children have complex needs: Two case studies. Communication Disorders Quarterly, 36(1), 44-54. https://doi.org/10.1177/1525740114525226

[10] Potter, S. L., \& Amanda, J. R.-S. (2012). Technology Integration for Instructional Improvement: The Impact Of Professional Development. International Society for Performance Improvement, 51(2), 22-27. https://doi.org/10.1002/pfi

[11] Anderson, C. A., Smith, R. L., Anderson, C. A., Smith, R. L., Computing, I., Anderson, C. A., \& Smith, R. L. (1984). Instructional Computing Patterns in Texas Schools : Implications for Teacher Training Instructional Computing Patterns in Texas Schools : Implications for Teacher Training. AEDS Journal, 1037(June), 1-16. https://doi.org/10.1080/00011037.1984.11008381

[12] Puentedura, R. R. (2006). Transformation, Technology, and Education: Understanding SAMR. Retrieved July 18, 2018, from http://hippasus.com/resources/tte/

[13] Batiibwe, M. S. K., Bakkabulindi, F. E. K., \& Mango, J. M. (2017). the SAMR Model Valid and Reliable for Measuring the Use of ICT in Pedagogy? Answers from a Study of Teachers of Mathematical Disciplines in Universities in Uganda. International Journal of Computing and ICT Research, 11(1), 11-30. Retrieved from http://ijcir.mak.ac.ug/volume11-issue1/article2.pdf\%0A1.

[14] Budiman, A., \& Ngadiso. (2018). EFL Teacher's Belief and Practice on Integrating Information and Communication Technology (ICT) in the Classroom. Asian EFL Journal, 20(4), 07-22.

[15] Cochrane, T., \& Antonczak, L. (2014). Implementing a Mobile Social Media Framework for Designing Creative Pedagogies. Soc. Sci, 3(September 2014), 359-377. https://doi.org/10.3390/socsci3030359

[16] Hilton, J. T. (2016). A Case Study of the Application of SAMR and TPACK for Reflection on Technology Integration into Two Social Studies Classrooms. The Social Studies, 107(2), 68-73. https://doi.org/10.1080/00377996.2015.1124376

[17] Jude, L. T., Kajura, M. A., \& Birevu, M. P. (2014). Adoption of the SAMR Model to Asses ICT Pedagogical Adoption: A Case of Makerere University, 4(2). https://doi.org/10.7763/IJEEEE.2014.V4.312

[18] Kihoza, Patrick, and Irina Zlotnikova, and Bada Joseph, and K. K. (2016). Classroom ICT integration in Tanzania : Opportunities and challenges from the perspectives of TPACK and SAMR models. International Journal of Education and Development Using Information and Communication Technology (IJEDICT), 12(1), 107-128. Retrieved from http://ijedict.dec.uwi.edu/viewarticle.php?id=2035

[19] Speirs, M. N. (2016). Assessing teachers' mobile device skills and the integration of technology into their lives. Ph.D. Thesis, State University of New York, Plattsburgh.

[20] Andersson, B., Nfuka, E. N., Sumra, S., Uimonen, P., \& Pain, A. (2014). Evaluation of Implementation of ICT in Teachers' Colleges Project in Tanzania. Stockholm: Citat. Retrieved from http://www.sida.se/publications

[21] Brás Pedro, M. G. L. and M. J. (2014). Teachers and Technology: A Complicated Relationship. Journal of Engineering Research, 2(1), 151-171. https://doi.org/10.7603/s40

[22] UNESCO. (2003). Developing and Using Indicators of ICT Use in Education. Ban: Education, UNESCO Asia and Pacific Regional Bureau for. Retrieved from 
http://unesdoc.unesco.org/images/0013/001311/131124e.pdf

[23] Lloyd, M. (2005). Towards a definition of the integration of ICT in the classroom. Proceedings AARE '05 Education Research - Creative Dissent: Constructive Soutions, 1-18. https://doi.org/10.1063/1.2130520

[24] Pelgrum, W. J. (2001). Obstacles to the integration of ICT in education: Results from a worldwide educational assessment. Computers and Education, 37(2), 163-178. https://doi.org/10.1016/S0360-1315(01)00045-8

[25] Thomas, T., Herring, M., Redmond, P., \& Smaldino, S. (2013). Leading Change and Innovation in Teacher Preparation: A Blueprint for Developing TPACK Ready Teacher Candidates. TechTrends, 55-63. https://doi.org/http://doi.org/10.1007/s11528-013-0692-7

[26] Doyle, H., \& Reading, C. (2012). Building teacher educator TPACK: Developing leaders as a catalyst for change in ICT Education. Future Challenges, Sustainable Futures. Proceedings Ascilite Wellington 2012, (2005), 272-282.

[27] Myers, J. (2017). Digging into the SAMR Model. Retrieved May 2, 2017, from https://www.gaggle.net/speaks/digging-into-the-samr-model/

[28] Puentedura, R. R. (2013). SAMR: Moving from enhancement to transformation. Retrieved from http://www.hippasus.com/rrpweblog/archives/000095.html

[29] Ahrens, A., \& Zaščerinska, J. (2014). Analysis of Teachers' Use of Web Technologies: Focus on Teachers' Enterprise 3.0 Application. Journal of Information Technology and Application in Education, 3(1), 25-32. https://doi.org/10.14355/jitae.2014.0301.04

[30] Dey, I. (2005). Qualitative Data Analysis (Second). Newyork: Routledge. Retrieved from snnetwork.org/sites/default/files/qualitative_data_analysis.pdf

[31] Ary, D., Jacobs, L. C., \& Sorensen, C. (2010). Introduction to Research in Education (Eighth Edi). Wadsworth, Cengage Learning.

[32] Denzin, N. K., \& Lincoln, Y. s. (2005). The Sage Handbook of Qualitative Research. (N. K. Denzin \& Y. s. Lincoln, Eds.) (Third Edit). London: Sage Publication.

[33] Miles, M., Huberman, M., \& Saldana, J. (2014). Qualitative Data Analysis. (H. Salmon, Ed.), Sage Publication (3rd ed., Vol. 1). California: Publications, Inc. https://doi.org/10.1080/0140528790010406

[34] Thomas, T., Herring, M., Redmond, P., \& Smaldino, S. (2013). Leading Change and Innovation in Teacher Preparation: A Blueprint for Developing TPACK Ready Teacher Candidates. TechTrends, 55-63. https://doi.org/http://doi.org/10.1007/s11528-013-0692-7 